\title{
The desire of power: Candidate ambiguity and incumbent monopoly in local leaders' election
}

\section{Keinginan berkuasa: Ambiguitas kandidasi dan monopoli petahana pada pemilihan kepala daerah (Pilkada)}

\author{
Erond L. Damanik \\ Department of Anthropology, Faculty of Social Science, Universitas Negeri Medan \\ Address: Jalan Willem Iskandar, Pasar V, Medan, North Sumatera 20221 \\ E-mail: eronddamanik@unimed.ac.id
}

Article History: Received 29 December 2019; Accepted 4 August 2020; Published Online 3 September 2020

\begin{abstract}
This study explores and discusses the phenomenon of a single candidate in the local leaders' election or Pemilihan Kepala Daerah (Pilkada) in Deli Serdang Regency, North Sumatra Province, in 2018. The study is motivated by the phenomenon of a single candidate in the local leaders' election. In Deli Serdang, the local leaders' election should have a multi-candidate pattern, either independent or 3-4 political party candidates. This study has focused on the mechanism of the emergence of a single candidate. According to Dahl, the theoretical approach is the candidacy mechanism, and according to Norris, the significance of the right to vote. The study was conducted qualitatively with an ongoing explorative, independent, and case-oriented study approach. The data collected through in-depth interviews with nine key informants consisting of the Political Party Branch Management Board or Dewan Pimpinan Cabang (DPC), the General Elections Commission or Komisi Pemilihan Umum (KPU), the Election Supervisory Committee or Panitia Pengawas Pemilihan (Panwaslih), independent, failed, and incumbent candidates. The sixteen secondary informants consisted of eight voting behaviors and eight non-voting behaviors randomly selected and interviewed to determine their perception of a single candidate. The study found that a single candidate is the logical consequence of ambiguity in an internal political party candidacy. The study's novelty is the exclusion of incumbent ruling candidates incentivizing a political party monopoly to ensure victory in contestation. The study concluded that the dysfunction of the candidacy and exclusion in power has implications for a single candidate in the local leaders' election. Contestation with a single candidate's presence is an uncontested election, and it is contrary to the theoretical paradigm referred to in this study.
\end{abstract}

Keywords: dysfunction; candidacy; monopoly; incumbent

\begin{abstract}
Abstrak
Studi ini bertujuan mengeksplorasi dan mendiskusikan fenomena kandidat tunggal pada Pemilihan Umum Kepala Daerah (Pilkada) di Kabupaten Deli Serdang, Provinsi Sumatera Utara, tahun 2018. Studi dilatarbelakangi fenomena kandidat tunggal pada Pilkada. Seharusnya Pilkada berpola multi-kandidat, baik independen maupun 3-4 kandidat partai politik di Deli Serdang. Masalah difokuskan pada mekanisme munculnya kandidat tunggal. Pendekatan teoretis digunakan adalah mekanisme kandidasi menurut Norris dan signifikansi memilih menurut Dahl. Studi ini dijalankan secara kualitatif dengan pendekatan ongoing exploring, indepth and case-oriented study. Data dikumpulkan melalui wawancara mendalam terhadap sembilan informan kunci, terdiri atas Dewan Pengurus Cabang Partai Politik (DPC), Komisi Pemilihan Umum (KPU), Panitia Pengawas Pemilihan (Panwaslih), kandidat independen, kandidat gagal, serta petahana. Enam belas informan sekunder terdiri atas delapan voting behavior dan delapan non-voting behavior, dipilih acak, dan diwawancarai untuk menemukan persepsi tentang kandidat tunggal pada Pilkada. Kajian menemukan bahwa kandidat tunggal adalah konsekuensi logis dari ambiguitas kandidasi di internal partai. Kebaharuan penelitian ini adalah eksklusi berkuasa petahana mendorong monopoli partai untuk memastikan kemenangan pada kontestasi. Penelitian ini menyimpulkan bahwa disfungsi kandidasi dan eksklusi berkuasa berimplikasi bagi kandidat tunggal pada Pilkada. Kontestasi dengan kandidat tunggal adalah uncontested election dan bertentangan dengan paradigma teoretis yang dirujuk pada studi ini.
\end{abstract}

Kata kunci: disfungsi; kandidasi; monopoli; petahana 


\section{Introduction}

The eleven political parties in Deli Serdang Regency who participated in the 2018 local leaders' election or Pemilihan Kepala Daerah (Pilkada) should have been able to present multiple candidates. The provision of ten House of Regional's Representative Assembly or Dewan Perwakilan Rakyat Daerah (DPRD) members and their support to run as a regent candidate compelled all political parties to form a coalition. The number of candidates should have amounted to six due to the additional two individual track candidates; however, the political reality in Deli Serdang Elections meant that there was only able to be a single candidate for the regional leader, referred to as a single candidate. The local election regulations in 2016 allowed the election to proceed where a single candidate competes against an empty box. This political reality has raised confusion. How can eleven parties support only a single candidate? Does the incumbent co-opt the eleven parties, or is it because of either pragmatism or transactional? Is the phenomenon of a single candidate a lousy record for the candidacy process in internal parties? Is there a possibility of intervention in the exclusion of power desire from the incumbent? This study intends to explore a single candidate's phenomenon based on two aspects: 1) the ambiguity of the candidacy mechanism, and 2) the power exclusion of the incumbent. It needs to be noted that power exclusion does not necessarily have to arise from the incumbent. It can also emerge from new candidates other than the incumbent.

The single candidate's phenomenon has appeared twice during the history of Indonesia's elections in 2015 and 2018. A single candidate shows the dysfunction of the parties' mechanism as agents of democratization. The dysfunction of the candidacy has terrible implications for democratization. The question that arises is why a multi-candidate is not present. Even if a single candidate is against an empty box is possible, is not the mechanism of a single candidate a paradox in terms of the democratization process? Furthermore, it feels strange if a multi-party system does not produce multiple candidates and instead results in a single candidate. The multi-party system thus failed to carry out its mission as agents of democratization. An election where the single candidate competes against an empty box is an uncontested election (Damanik 2018a). Reasonable contestation should pit at least two contestants against one another, so the public can consider which best candidates to channel their aspirations. Multi-candidate creates a climate of capability in the democratization process.

Election through the multi-candidate is of better quality than a single-candidate election. Multiple candidates not only have an impact on public goods; however, they also contribute to the democratization process at the national level (Gill 1995). In the context of decentralization, local political dynamics and governance are related to national democracy's face - the correlation between democratization at the local and national level formed through high-quality political selection and recruitment. Multilevel recruitment and a suitable candidacy mechanism are intended to attract potential candidates from different regions. It is launched at the national level (House of Representative Assembly or Dewan Perwakilan Rakyat (DPR), Regional Representative Assembly or Dewan Perwakilan Daerah (DPD), and president); however, the parties' candidacy in several regions presented with failure upon a single candidate'semergence. Therefore, localelections cannotbecomprehensivelyused toindicate the success of democratization (Sarman 2015). The elections' results have not been applied fairly and prosperously because they eliminate the sovereignty holders (Freeman 2007, Rawls 2008, Rhodes et al. 2008).

The local election is a democratic system instrument. Theoretically, Indonesia's political dynamics have improved since the reformation era (Triono 2017). However, upon close examination, the implementation of elections only satisfies the procedural steps rather than the more substantial ones. The indicators of successful elections are not just determined based on the most number of votes; however, the determinant lies in the quality of the substance of democracy for the community (Surbakti 2010). This study aims to deconstruct and understand the emergence of a single candidate and the incumbent monopoly. The main problem is emphasized in the process that resulted in a single candidate. The two main concepts of the study are ambiguity and monopoly. The former concept refers to the mechanism of recruitment and the selection of leaders candidates within the party environment. The latter concept refers to the incumbent's monopoly over all of the parties. Both ambiguity and monopoly are social and political realities in Deli Serdang, which indicates the parties' inability to independently determine a candidate and the ruling exclusion of the incumbent. 


\section{Research Method}

This study was conducted qualitatively focused on the process, meaning, experience, and appreciation of the subject (Creswell \& Creswell 2017). Qualitative research is intended to understand the situation based on phenomena and social realities. The study's approach is an ongoing exploration where the exploration is still ongoing despite the local elections' completion. The primary tool used for the data collection was in-depth interviews of the nine key subjects and sixteen secondary subjects. The nine key subjects consisted of the Board of Political Party Branch or Dewan Pimpinan Cabang (DPC), the Election Commission or the Komisi Pemilihan Umum (KPU), the Election Supervisory Committee or Panitia Pengawas Pemilihan (Panwaslih), the independent, the failed, and the incumbent candidate. The sixteen secondary informants were people who have the right to vote, consisting of eight informants who channeled their political rights and another eight is a non-voting behavior. The sixteen subjects were randomly selected and interviewed to find out the perceptions of the single candidate. In addition to interviews, other data sources were documents in the form of the minutes of the internal party meetings, correspondence, or reports obtained from the KPU, Panwaslih, and $D P C$ offices. Research into these documents has contributed to the reasons behind candidacy, the ambiguity of parties, and the incumbent monopoly.

The subjects were determined based on the research objectives and a single candidate's phenomenon during the candidacy process. This study's assumptions are 1) the ambiguity of the party candidacy, and 2) the power exclusion of the incumbent. The final step was a discussion and interpretation to formulate the research findings, novelty, conclusions, and contributions.

\section{Result and Discussion}

\section{An ambiguity of the regional leaders' candidacy in Deli Serdang}

The phenomenon of a single candidate appeared twice in the regional contestation in 2015 and 2018. The emergence of a single candidate cannot be separated from election regulations. The 2015 elections have stipulated under Law Number 8 the Year 2015 concerning the election of governors, regents, and mayors. Referring to this regulation, an election is only possible if it consists of two candidates. The regulation does not accommodate a single candidate, in other words, if there is only a single candidate, then the candidate registration period must be extended to meet the provisions of the article. The rigidity of this regulation became evident in the 2015 elections. Upon closing the registration period in July 2015, there were eleven single candidates out of 269 elections. Even though the registration period was extended twice, it still resulted in a single candidate. Nationally, the first and second registration extensions at the beginning and end of August 2015 left seven and three single candidates.

Based on the above facts, the law was updated by issuing Law Number 10 the Year 2016 concerning the election of governors, regents, and mayors. The new regulation accommodates the possibility of a single candidate. In 2018, a total of 171 regions in Indonesia held elections simultaneously. In that year, fifteen single candidates out of 568 regional took part in the election (Komisi Pemilihan Umum 2018). There were two regions in North Sumatra Province with a single-candidate; Deli Serdang and Padang Lawas Utara Regency. The regional leader candidate who seized power was the incumbent, Ashari Tambunan. He continued his term as regent for a second period. Based on the DPRD seat acquisition composition, no party can carry its candidates forward. The provision for the parties being able to support one candidate for the election was ten seats. The coalition of parties could have brought up four candidates forward for the election. This number was likely to increase because there were two candidates from individual lines. Table 1 outlines the composition of the DPRD for 2014-2019.

Members of the parties initially dominated the selection of the leading candidates. Five $D P D$ and $D P C$ chairmen who had garnered more significant votes in the DPRD said they were endorsing Golongan Karya Party (Golkar), Gerakan Indonesia Raya Party (Gerindra), Amanat Nasional Party (PAN), Demokrat Party (PD), and Demokrasi Indonesia Perjuangan Party (PDIP). However, until the 
candidate registration period was closed by the $K P U$, it turned out that none of the parties was able to form a coalition to carry the candidates forward. Only the incumbent, Ashari Tambunan, partnered with Yusuf Siregar, received the coalition's support to run for a second period. The candidate had been promoted by the Demokrat Party (PD), which only had five seats in the DPRD. Not coincidentally, Anita Lubis, chairman of the PD-DPC, was the incumbent's sister-in-law and Amri Tambunan's wife. This fact made it easy for Tambunan-Siregar to successfully lobby and bring the other parties into the PD coalition.

Table 1.

Composition of DPRD, 2014-2019

\begin{tabular}{lc}
\hline \multicolumn{1}{c}{ Political party } & Number of seats \\
\hline Golongan Karya & 8 \\
Gerakan Indonesia Raya & 6 \\
Demokrasi Indonesia Perjuangan & 6 \\
Amanat Nasional & 6 \\
Demokrat & 5 \\
Keadilan Sejahtera & 4 \\
Hati Nurani Rakyat & 4 \\
Nasional Demokrat & 3 \\
Kebangkitan Bangsa & 3 \\
Persatuan Pembangunan & 3 \\
Keadilan dan Persatuan Indonesia & 1 \\
\hline \multicolumn{2}{c}{ Total } \\
\multicolumn{2}{c}{ Source: Komisi Pemilihan Umum (2018) }
\end{tabular}

The PD support letter to the incumbent was handed over by Hinca Panjaitan (Secretary of the PDCentral Board or Dewan Pimpinan Pusat (DPP)) and Anita Lubis. Until the candidates' registration, nine parties had provided support to the incumbent with the total support of forty-three seats. The other two parties, Gerindra and Keadilan dan Persatuan Indonesia Party (PKPI), who had seven seats combined, could not endorse their candidates. Both parties failed to form a new alternative candidate, and finally, they channeled their support toward the incumbent. In the end, the incumbent, in the 2018 Deli Serdang Election, monopolized eleven parties.

The condition of national politics, represented by the PD, was utilized in Deli Serdang. Generally, the ruling party's transition changes and the ruling official are not a secret and can be interpreted as a way of finding a "safe position." The Tambunan family responded to national politics by seizing control of the PD; it began to occur during the second period of Amri Tambunan's as Deli Serdang regent. Their instinct and desire to be in power became even more apparent when Anita Lubis was elected chairman of the PD-DPC. Anita Lubis ensured that the pathway for the Tambunan clan to advance to the regional election was clear. Furthermore, there is an effort to form Tambunan clans by preparing either Anita Lubis or her child for the 2022 elections.

The selection of the regional leader also attracted candidates from the individual track. Two individual candidates bring diversity to the local leader candidacy; Nasution-Jamilah and Tarigan-Abidin, both candidates, sought support from the community. In terms of ethnicity, the two Muslim candidates came from the Mandailing, Karo, and Javanese. However, the two individual candidates' registration documents were annulled by the $K P U$ due to the lack of support, which required a National Identity Card or Kartu Tanda Penduduk (KTP) 87.496 supporters. Both candidates were asked to complete the file during the grace period, but they could not complete it by the deadline. Finally, the $K P U$ eliminated the nomination of the two individual candidates.

Both candidates filed their appeal against the annulment to the Panwaslih. However, the Panwaslih's decided to affirm the KPU's decision because the two candidates did not complete the required documents. Candidate Tarigan-Arifin was said to be late submitting the required documents within the time limit while Nasution-Jamilah was said to be unable to complete the missing files. The rumor of the incumbent's intervention in the two candidates' annulment decision was circulated in the community, which included money politics from the incumbent to Panwaslih and KPU. 
According to both the parties and the individual track, the requirements of the regional leader candidacy involve a very general and common provision. The difference between the two channels lies in the requirement to include the citizens' support by submitting the KTP of the individual candidates. The provisions for candidacy are regulated in Article 4 of KPU Regulation Number 3 the Year 2017 concerning the Nomination of the Election of the Governor and Vice Governor, Regent and Vice Regent and/or Mayor and Vice Mayor. The stages of the 2018 elections following the provisions of the KPU can be seen in Table 2.

Table 2.

Stages of the Regional Election in 2018

\begin{tabular}{ll}
\hline \multicolumn{1}{c}{ Dates } & \multicolumn{1}{c}{ Election components } \\
\hline 31 July 2017 & Submission of DAK-2 \\
24 Nov-30 Dec 2017 & Processing of DP-4 and voter updates \\
1 Jan 2018 & Registration of the prospective candidate \\
8 Feb 2018 & Announcement of the leader candidate \\
15 Feb 2018 & Campaign period \\
24 Jun 2018 & Quiet period and campaign attribute cleaning \\
27 Jun 2018 & Election time \\
28 Jun 2018 & Result recapitulation \\
\hline & Source: Komisi Pemilihan Umum (2018)
\end{tabular}

The candidacy mechanism for the parties begins at the grassroots captured by the $D P C$, followed by consulting with the $D P D$ to obtain approval from the $D P P$. The event where either the $D P C$ or $D P D$ does not register a candidate, the $D P P$ of the party may register the candidate in which the general chairman and the secretary-general sign the registration documents. Regional registration is still carried out by the parties that mandate the elections in the regions where the elections occur.

Although the candidacy process commenced from the $D P C$, their decision and authority were not absolute because the $D P D$ or $D P P$ could have annulled it. Tiered candidacy mechanisms are prone to veiled transactionalism. A political dowry or "boat money," is paid to the $D P C, D P D$, or even the $D P P$ to smooth the internal parties' candidacy. Despite the difficulty associated with proving it, the political dowry discourse echoes every momentum of the elections. The allegation that a political dowry is a common practice in elections can be concluded from the parties' statement, which mentioned a mechanism to appoint and determine candidates "without a dowry." For example, Ridwan Kamil, a candidate endorsed by Nasional Demokrat Party (NasDem) in the West Java Governor, was labeled a "without a dowry." This statement did not emerge from the eleven parties endorsing the single candidate in the Deli Serdang election or the nine parties carrying the Eramas forward in the North Sumatra Governor Election. However, political dowries sometimes do not apply to potential candidates who have a positive image or figure who have high popularity and electability. It should be underlined that a political dowry does not include only the transactions done during the candidates' initial determination. It can also happen after the victory of the endorsed candidates. The "political dowry," in this case, becomes "budget politics," which channeled into the coalition that participate in the victory.

The emergence of a single candidate in the Deli Serdang Election results from the ruling parties and the incumbent's instinct for power. Since the beginning, the incumbent has formed a joint axis as part of a coalition to register themselves for the upcoming election. The minimum requirement of ten $D P R D$ seats to endorse a candidate should have made them refuse other parties' support to enable the possibility of a new political axis to give room for more competitive contestation. However, the incumbents still received a coalition offer that enabled the other parties to join with them. As a result, all of the parties joined the incumbents' coalition. Having all of the parties join his bandwagon, the incumbents further smoothed his way to being re-elected as regent. It was possible because of 1) all parties' components framing the public opinion to elect a single candidate, and 2) the zoning of the electoral districts to achieve a minimum number of votes, $30 \%$ of all who cast a vote. 
The political calculation is inseparable from the identity politics that utilize religion and ethnicity. Ethnically, the victory of Tambunan-Siregar is more determined by the ethnic groups of the Toba, Simalungun, Mandailing, and Javanese (Damanik 2018b). The Malay, the host ethnicity, tends to display a non-voting behavior. For parties, the instinct for power is calculated tactically and politically, including the difficulty of defeating the incumbent. They are considered to control the resources, bureaucracy, and patronage that have been formed previously. The parties' interests are grounded in how to rule and divide the local resources after being elected. Often these interests ignore their function as agents of democratization, and thus they are trapped in practical politics. These issues are the reasons behind the failure of the multi-candidate.

The parties' inability to present multiple candidates for the election raises concerns regarding the parties' candidacy mechanism; however, it also brings in the sense of doubt about parties' function as a mechanism of checks and balances for five years (2018-2023). It means that there is no opposition to evaluate the government. The parties' monopoly affects the accountability, capability, and transparency of the ruling government, which triggers an absence of accountability, equity, and local responsiveness. The candidacy mechanism at the internal party level is very centralistic as well as a complicated process. The presence of Djarot-Sihar, who was endorsed by the coalition of PDIP and Persatuan Pembangunan Party (PPP) during the election for the governor of North Sumatra shows the unique phenomenon of internal party candidacy, as does the failure of two prominent figures in the parties' failure to run for the election. The Nuradi candidates were the incumbent governor, the chairman of the DPD NasDem backed by eight DPRD seats, and Sitepu, the twoterm serving Langkat regent, the chairperson of Golkar $D P D$ who won seventeen seats in the North Sumatra $D P R D$. The failure of these two governor candidates who had nominated themselves from the beginning was a big question.

Four parties dominated the DPRD seats-Golkar (eight seats), Gerindra, PDIP, and PAN (six seats) failed to form the inter-party collaboration necessary to endorse their candidates. Meanwhile, the PD, which only has five seats, successfully entered their candidate. Ironically, they were able to monopolize all of the other parties under them. The cadres of the parties wanted to run for the election; however, there were reasons why they canceled their nomination; 1) limited economic resources to reach the area, 2) a lack of support from the $D P D$ or $D P P$ to run for the election, 3) the lack of support from the grassroots community for the party cadres, and 4) the consideration of the party cadres to be able to defeat the incumbent. Anita Lubis played an essential role in the victory of Tambunan-Siregar. It involved political experience and networking in the local and national level during the second period of Amri Tambunan, in addition to facilitated lobbying and political negotiations with the nine $D P C$ Parties, the prominent supporters of Tambunan-Siregar. Anita Lubis's expertise and political lobbying skills have been proven by her ability to damage the multiple candidate cancellation.

In an interview with Anita Lubis on $18^{\text {th }}$ November 2018, she explained the following:

\footnotetext{
"The main purpose of the election is the victory of a candidate (we) supported. At that time, of course, we supported Tambunan (I think you already know the reason), especially for his second period. All political processes and mechanisms have been completed well. Initially, Democrats lobbied PAN and PKB to form a coalition. We got (them). However, the heads of other parties provided support for the candidate endorsed by Democrat. Nearing the closing, two other parties, Gerindra and PKPI, declared joining (the coalition). We appreciate that we accept (them). There was no money we paid, no promises behind the closed curtain, boat money, or political dowry. All of them supported our candidate because of his performance in the first period. Everything is for the progress of the Deli Serdang."
}

Besides, the failure of individual candidates to advance to the contestation due to several reasons: 1) their inability to complete the required documents, 2) the negative paradigm framing the parties, the political dowry or "boat money," that must be met by the candidates, 3) the assumption that parties use two candidates to drain their material resources, 4) the perceived lack of seriousness of 
the parties, wing organizations, and members, and 5) the centralized party mechanism involved in political decision-making. This assumption is a consideration for the candidates when they turn from the party to the independent track. However, individual candidates are vulnerable to defeat by parties during the candidacy process, including by electoral institutions that wish to frustrate them during the nomination stage.

The interview with Tarigan on $22^{\text {nd }}$ November 2018, an individual candidate who failed to advance in the election, involved the following:

\begin{abstract}
"As a resident of Deli Serdang, I am ashamed to see the 2018 elections. Why? Eleven political parties only endorse one candidate, which is the incumbent. Well, those eleven political parties should have been able to carry four pairs of candidates on top of two pairs of independent. Therefore, there will be six candidates in total. That would have been good! Instead, eleven political parties endorsed one candidate, and on top of that, KPU and Panwaslih cut off the independent route. Our file was declared late, while candidate Nasution's was declared incomplete. How could that be! Our file was completed from the start. The KPU was bribed. Just look at the incumbent's performance on his second period; there were none. Therefore, if there were more than one candidate, surely the incumbent will lose. Thus, they tried to make us failed, including (interfering) parties not to endorse any candidates, and they are all paid."
\end{abstract}

The difficulty of the parties to determine their candidates for the election is due to several reasons: 1) overly complex and tiered candidacy mechanism including the $D P C, D P D$, and $D P P, 2)$ political dowry and campaign financing that is considered burdensome for candidates; and 3) the crisis of confidence in parties as a structure and the integrity of their leadership. This situation has become a significant factor in parties' failure to come up with a candidate, and the reality in Deli Serdang conflicts with that stated by Norris (2006), which the failure parties to potential candidates. This dysfunction is related to; 1) the authority that controls the selection process, 2) the engagement of the national party leaders' role at the main level, 3) the role of party leaders at the regional level, 4) the role of the party leaders at the election level, and 5) grassroots and youth organization parties.

The phenomenon shows that there are two forces involved in candidacy, both formal and informal. These are internal parties, election institutions, and the community. This consideration means that the parties do not have absolute authority to decide on the candidates who run in the elections. Referring to the candidacy in the Sidoarjo (Situmorang 2016) it has similarities with Deli Serdang. According to Situmorang (2016), the candidacy within the internal Kebangkitan Bangsa Party (PKB) was carried out openly during the selection process. The entire candidacy process moves to the election desk team determined by the DPC and East Java PKB central board. They must obtain a $D P P$-PKB recommendation. Although the candidates' determination is decentralized, the selection process is carried out by $D P C$, and it is tiered to a higher level exclusively. This situation shows that $D P C$ does not have the absolute authority to determine the candidates. They must obtain approval and recommendations from a higher level.

Looking at the process of candidacy in Deli Serdang, a secret political game seems to takes place involving internal parties, electoral institutions, and grassroots organizations. Even though it is difficult to prove, a confession from a subject of this research mentioned transactionalism as a strong reason behind multiple candidate failure. Unsurprisingly, the incumbent monopoly on parties results in the absence of opposition in the government. Resource hijacking is prone to happen, and the government mechanisms will not function properly due to the opposing parties' lack of supervision. It is where the parties' role as an agent of democratization in the regions questioned. The parties trap in the sense of pragmatism and transactionalism. It has been occurring since the candidacy process began in the contestation, where the resources and interests became a political reference. The candidate's character highlighted no longer based on their public image, performance analysis, or managerial ability. It turns to the strength of their resources and material offerings. Therefore, the existence of parties should not be used as an indicator of democratization. This situation is very confusing for the community where the parties cannot be expected to be a structure of change, maintain leadership's integrity, evaluate performance and balance power, or sympathize with the voters' owner. 


\section{Contestation without competition}

It has been explained that the ambiguity of candidate and the incumbent's monopoly has led to the emergence of a single candidate in the election. Contrary to the election in 2015, which did not accommodate a single candidate, the 2018 election has. This practice is under Law Number 10 the Year 2016, where the election is a contest between a single candidate and an empty box. This provision is a win-win solution to satisfy the procedural requirements of elections. Although it still follows the election procedures, the contestation of a single candidate against an empty box is not a reflection of the best competition, and it harms the process of democratization. In other words, the mechanism for selecting a single candidate against an empty box is an uncontested election.

The single candidate, Ashari Tambunan, is Amri Tambunan's brother, both were born into military families, and his father is Djamaludin Tambunan. His father held positions such as the regent of Tanjungbalai, Asahan, Simalungun, and Labuhanbatu, mayor of Pamatangsiantar, the young governor of North Sumatra, governor of Jambi, and head of Research and Development of the Ministry of Home Affairs. He was also a member of the DPR, before serving as regent, Ashari Tambunan held the central position of chairman of the Sumatra and North Sumatera Nahdatul Ulama Regional Management. His position in Nahdatul Ulama led him to the Deli Serdang Election in 2014, where he went on to take the baton from his brother, Amri Tambunan.

On $23^{\text {rd }}$ October, in the 2014 elections, Ashari Tambunan, paired with Zainuddin, won the contestation, supported by the PAN, Gerindra, PKB, and PBB. At that time, there were seven pairs of contesting candidates, two of which were carried out by parties while the remaining five were from individual tracks. At that time, the social forces were fragmented according to each candidate. It reflects the power of ethnicity (Damanik 2018b; 2019a). The Javanese, Karo, and Malay had their candidates, while the Ashari Tambunan reflected a small ethnic group. In the 2018 elections, a single candidate was confronted with an empty box as. Table 3 below is the recapitulation of the Deli Serdang Election in 2018.

Table 3.

Recapitulation of the voters' count in the Deli Serdang Election in 2018

\begin{tabular}{lrrr}
\hline District & Incumbent & Empty box & \multicolumn{1}{c}{ Invalid } \\
\hline Lubuk Pakam & 23.644 & 8.745 & 3.480 \\
Birubiru & 10.409 & 3.275 & 1.655 \\
Kutalimbaru & 10.280 & 4.124 & 978 \\
Bangunpurba & 7.643 & 1.685 & 956 \\
Hamparan Perak & 46.595 & 7.692 & 11.898 \\
Pancurbatu & 10.280 & 4.124 & 978 \\
Tanjung Morawa & 65.548 & 13.641 & 956 \\
STM Hilir & 8.273 & 3.119 & 3.960 \\
Patumbak & 24.001 & 6.070 & 3.216 \\
Delitua & 16.687 & 3.793 & 2.285 \\
Batangkuis & 17.502 & 3.103 & 3.960 \\
Sibolangit & 7.725 & 1.591 & 713 \\
Gunung Mariah & 1.184 & 1.813 & 1.591 \\
Pagarmerbau & 13.278 & 1.813 & 1.781 \\
Labuhandeli & 19.434 & 2.559 & 2.300 \\
STM Hulu & 4.409 & 1.108 & 414 \\
Namorambe & 11.918 & 3.637 & 2.121 \\
Beringin & 16.521 & 2.043 & 1.800 \\
Percutseituan & 109.566 & 17.223 & 10.824 \\
Galang & 21.229 & 3.899 & 2.361 \\
Pantelabu & 10.961 & 2.317 & 2.205 \\
\hline \multicolumn{1}{c}{ Total } & $\mathbf{5 3 9 . 3 9 3}$ & $\mathbf{1 1 4 . 2 5 8}$ & $\mathbf{7 1 . 5 8 2}$ \\
\multicolumn{1}{c}{ Percentage } & $\mathbf{8 2 . 5 2 \%}$ & $\mathbf{1 7 . 4 7 \%}$ & $\mathbf{1 0 . 6 6 \%}$ \\
\hline \multicolumn{1}{c}{ Source: Komisi Pemilihan Umum $(2018)$} \\
\end{tabular}


Table 3 shows that a single candidate leads the number of votes in the elections. By the total 653.651 valid voting votes, the single candidate won 539.393 or $82.52 \%$, while the empty box gained 114.258 or $17.47 \%$. The percentage of voting behavior was $57.58 \%$ or 671.233 of the 1.165 .762 total permanent voters list or Daftar Pemilih Tetap (DPT) while non-voting behavior reached $42.42 \%$ or 494.529 voters. The incumbent candidate victory only reached $46.26 \%$ of the total $D P T$. This percentage shows that a single candidate's victory is less than $50 \%$ of the total $D P T$. Figure 1 shows the comparison between the totals for voting, non-voting and valid votes.

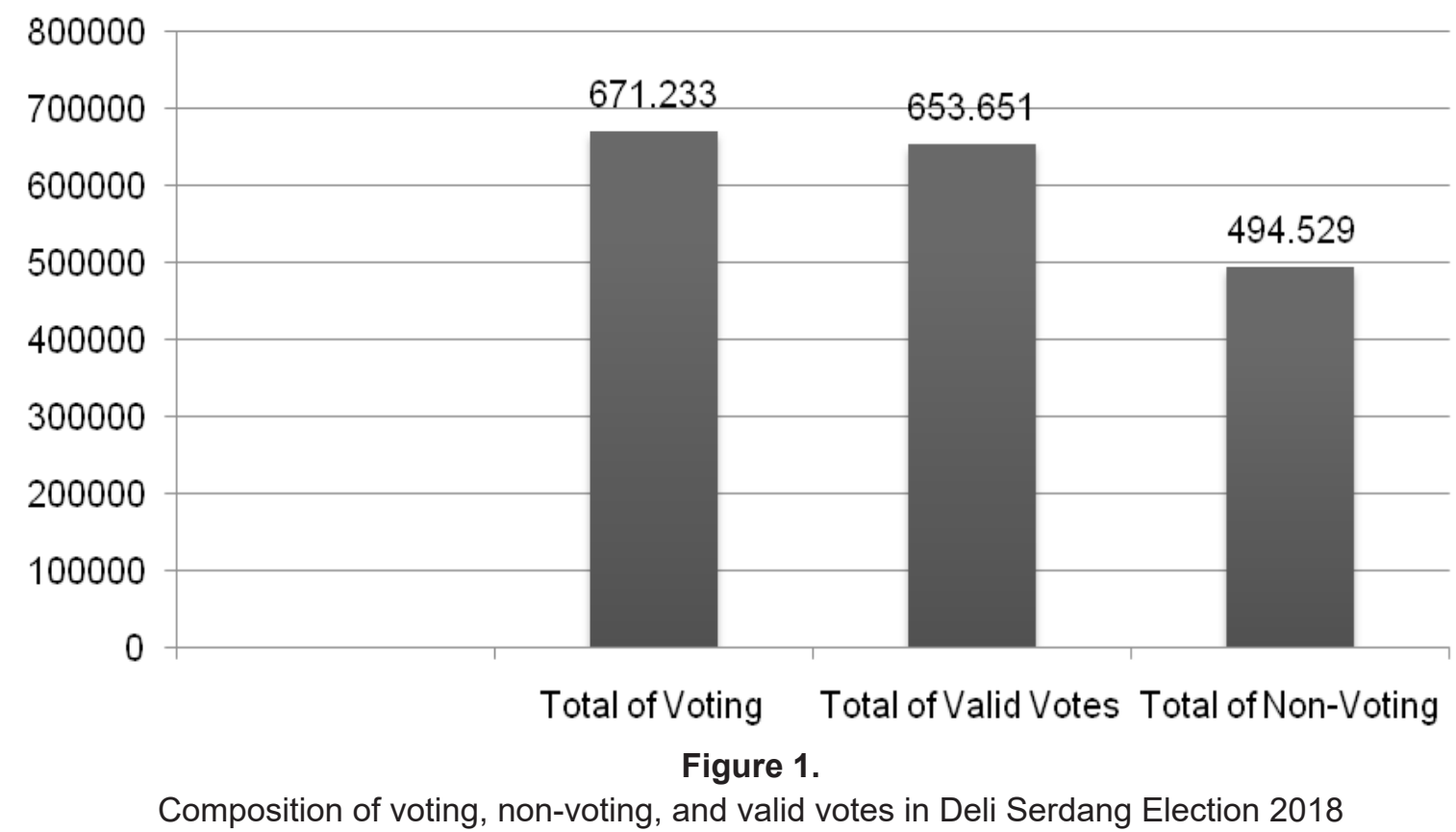

The districts with the most massive turnout in Deli Serdang were Percut Sei Tuan, Tanjung Morawa, Hamparan Perak, and Patumbak. The vote accumulation in these four regions amounts to half of the total DPT. A closer look at the recapitulation of vote-counting in Table 3 shows the reality in which an empty box always gets a vote. In that sense, the existence of incumbent candidates always garners some rejection in each district even though the percentage is relatively small. Table 3 shows interesting phenomena in six areas: 1) Lubukpakam District, the incumbent, received 23.644 while the empty box had 8.745 . As the district capital, the community is plural, and there is high mobility. They were the first to receive more information about the incumbent's performance, making them more rational when determining their regent. 2) Hamparan Perak District, the incumbent, won 46.595 while the empty box received 7.692.

The accumulation of invalid votes and empty boxes made up half of the incumbent votes. This area is a community settlement dominated by Malays. The Malays, everyone who has a family name, still receives doubt about their personality (Damanik 2019b). The next, 3) Percut Sei Tuan District, dominated by Javanese and the most extensive electoral area in Deli Serdang. That is why every candidate cannot ignore this electoral district. In this region, the incumbent won 109.566, while empty boxes received 17.223. 4) Tanjung Morawa Districts, the incumbent, won 65.548 while empty boxes received 13.641. This area, which is directly adjacent to Lubuk Pakam and Medan City, had its interests in the elections, due to both the business owners and employees.

The mobilization of employees to select specific candidates is possible, especially concerning the Regional Minimum Wage or Upah Minimum Regional (UMR) and the ease of bureaucracy. 5) Patumbak District, an area dominated by the Karonese, the second-largest voter population after the Javanese. In this area, the incumbent won 24.001, while empty boxes received 6.070. 6) Gunung Mariah District, the incumbent, suffered defeat and only received 1.184, while the empty boxes won with 1.813. Official working visits rarely happened in this area, so they harbored a sense of disappointment that was then vented by voting for an empty box. 
A single candidate's victory in the 2018 election also took place in the Padang Lawas Utara Regency. In this region, candidate Andar-Hariro won the contestation with 84.339 or $80.56 \%$, while the empty boxes received 20.369 or $19.44 \%$ of the total 143.590 DPT. Previously, the victory of a single candidate in the election occurred in Tebing Tinggi in 2015. In that year, the single candidate Hasibuan-Siregar won the contestation with 41.937, while the empty box received 16.861 votes out of 106.940 DPT. Another single candidate victory took place in Mamasa, West Sulawesi, where the single candidate Badawi-Tiranda won $62 \%$ of the votes. A single candidate's victory in the 2018 election in two regions in North Sumatra was different from Makassar, where the empty box defeated the single candidate. The voters' acquisition of candidate Afifuddin-Dewi in Makassar only reached $47.50 \%$, while the empty box won $52.50 \%$.

The political reality in Makassar is due to the ego for the power of the candidates who sweep up all of the other parties so than any other candidates do not get the opportunity to join the contest (Yunus 2018). According to Yunus (2018), the candidate's monopoly over the other parties shrouded in secret games within the party and election institutions and at the grassroots level. The sixteen single candidates who competed in the 2018 elections won (Deli Serdang, Padang Lawas, Prabumulih, Lebak, Tangerang, Pasuruan, Tapin, Bone, Enrekang, Southeast Minahasa, Puncak, Jayawijaya, and Central Memberamo) while one (Makassar) was declared defeated. The sixteen single candidates' apparent pattern is related to the parties' monopoly that is generally carried out by the incumbent. The emergence of a single candidate clearly shows the loss of the parties' function as democratization agents. This phenomenon shows the vanishing hope in parties as a structure and their role as checks and balance mechanisms. Although empty boxes are available to carry out contestation against a single candidate, this is not a competitive election. Empty boxes are only a form of venting anger and disappointment as the community members cannot represent their desires as regional officials.

An election without contestation is caused by three main factors: 1) institutional or legislative, 2) the failure of the political parties to endorse multiple candidates, and 3) the ego of the ruling of the candidates who sweep up all parties (Manan 2015). The necessity of a contested election is based on three considerations: 1) the institutional arrangements are undertaken to reach political decisions through competitive struggles to get votes (Schumpeter 2008), 2) it presents a responsive democracy, which involves elected officials, free and fair elections, inclusive voting rights, and the right to compete to seize a public position (Dahl 1989), and 3) it provides support or legitimacy for the decision-makers (Maisel \& Brewer 2016).

Uncontested election shows the failure of the democratic process; 1) the limiting of the citizens' political aspirations to choose and determine candidates, 2) the political delegitimation of the government power and authority (Ball 1988), and 3) the failure of the parties to present multiple candidates for fair competition (Diamond \& Gunther 2001). The elections are a political strategy concerning situational analysis, strategic and tactical decisions, and implementation (Schroder 2008). Internal, a candidate's victory is determined by the political engine and institutionalized structure down to the grassroots (Sari 2017).

The substance of democracy refers to the community's role and involvement to create accountability and responsiveness in the local government (Dahl 2001). The substance of democracy is achieved through the elections process, which reflects citizens' political life as a pillar of democracy that prioritizes the interests of its citizens (Surbakti 2011). The substance of democracy impacts the community who participates in choosing and controlling their government. Communities, concerning the concept of democracy, have independent power over themselves when determining their choices (Nurtjahjo 2006). The community has an enormous interest in changes its leaders, in addition to testing and evaluating the quality and the quantity of support for the successes and shortcomings of the leaders as well (Basariyadi et al. 2012). Contestation requires community participation.

Community participation is an indicator of success in the election (Huntington 1984). However, the level of participation does not always correlate significantly with the quality of the election. It only 
influences its legitimacy (Akbar 2016). The quality of the local contestation is made possible through political education, outreach, communication, articulation, and the aggregation of organizing the election that is grown through democratization agents, the political parties. An election should be the momentum needed for national political growth that takes place in a state of fair and open competition (Afifulloh 2015). In the framework of being agents of democratization, parties hold central control.

The parties have failed to fulfill their function as agents of democratization. Their dysfunction illustrates the three main problems of democratization: 1) the failure of the internal candidacy process to find and nominate potential candidates, 2) the ambiguity of the parties to choose and determine cadre and non-cadre candidates, and 3) individual candidates reflecting the structural failure of the quality and integrity of the parties. Beyond the three main issues above, there is the exclusion of power, both from the incumbent and new candidates. However, the exclusion of power can be overcome if the parties are of good quality and integrity. On the other hand, democratization is hampered if the parties' main channels of participation fail to orbit potential candidates in contestation.

The phenomenon of a single candidate in the election points to four main issues: 1) the dysfunction of parties as the main engines of democratization, 2) the failure to increase the vital political participation to gain power and legitimacy, 3) prioritize the instinct for power, and 4) the failure as an agent of democratization. Political parties play a central role in presenting multi-candidate mechanisms. The empowerment of the party cadres is essential, and it is done through functionary training, leadership schools, organizational experience, formal and non-formal education criteria to shape the leaders' soul and character (Razaqtiar 2016). Political parties' position in the local election era still shows that it has a dramaturgical (Cohen 1981), which is an artificial contrast between the front and back stages (Goffman 1959). In a sense, people as sovereignty owners are treated as passive spectators (Derrida 1978), and they tend to accentuate their selfish inclusiveness (Reynold \& Herman-Kinney 2003).

One way to look at the substance of democracy is the availability of contestation space through the multi-candidate mechanism. This mechanism affects the elected candidates' moral burden and political responsibility. The parties supporting the losing candidates will act as an opposition. Being a member of the opposition is expected to create a balance within the government (Marijan 2011). The function of parties is lost if contestation takes place with only a single candidate. The parties are transformed into democratic hijackers. Although empty boxes are available as choices, this method shows the decline of democracy in the modern era. Empty boxes do not bring about any good for the substance of democracy-it merely satisfies it as a procedural requirement. A single-candidate election is more motivated by the power of desire. The study's findings are as follows: 1) the emergence of a single candidate is due to ambiguity in the candidacy mechanism in the context of internal parties, 2) a single candidate is a dysfunction of the parties' role to find potential candidates, 3) an empty box versus a single candidate is an election without contestation, 4) the coalition of parties endorsing a single candidate attempts to fulfill the ruling instincts both practical and political interests, and 5) the brotherhood network between the incumbent and the chairman of the political party.

The success of the candidacy process is influenced by several things: 1) the authority that controls the selection process, 2) the role of the party's leadership at the central level, 3) the function of the party leader at the regional level, and 4) the grassroots or party youth organization. The process of the candidate goes through a four-tiered analysis: 1) the legal system concerning the legal rules, parties, and elections that open up opportunities for candidates, 2) the recruitment process with a degree of democracy within the parties and the provisions governing candidate selection, 3) bidding candidates who wish to be elected to occupy certain positions as a consequence of political motivation and capital, and 4) the demands of supporters or political leaders who conduct the selection (Norris 2006). Candidate selection is the party's treatment of all stages of political recruitment. The party's efforts to organize themselves against the phenomena that occur during the process of candidacy consider four main points: 1) the inclusivity and exclusivity among the nominated candidates, 2) the selectors, the selecting agency which is inclusive or exclusive, 3 ) the place of selection, whether it is centralized or decentralized, and 4) the efforts were undertaken to nominate the candidates, in addition to the election or appointment mechanism (Rahat \& Hazan 2001). 
The research contributions affirm Norris's theorization of candidacy and Dahl's about the importance of contestation. A healthy candidacy affects competitive contestation when it comes to producing regional leaders who possess local accountability, political balance, and responsiveness. Multiple candidates from both the political parties and independent tracks are very dependent on the process of candidacy.

\section{Conclusion}

The phenomenon of a single candidate in the regional election is summarized in the ambiguity of the candidacy that appears in the incumbent's domination over the political parties. Taking up all of the parties' support is a display of the ruling instinct and their desire to be in the regional power circle. Ambiguity is caused by four main factors; "boat money," contestation costs, campaigns, and elections. A single candidate is the failure of political learning within the internal parties to find potential candidates. This study concluded that a single candidate is a dysfunction of the candidacy in internal parties. The exclusion of other candidates from power is the reason for the monopolization of the parties. The political reality of regional election today shows that there is a connection between the incumbent candidate and party leaders. This study contradicts Norris and Dahl's paradigm on the urgency and significance of candidacy and multiple candidates in the democratic process.

\section{References}

Akbar I (2016) Pilkada serentak dan geliat dinamika politik dan pemerintahan lokal Indonesia. Jurnal Ilmu Pemerintahan Cosmogov 2 (1):95-110. https://doi.org/10.24198/cosmogov.v2i1.11852.

Ball AR (1988) Modern Politics and Government. London: MacMillan.

Cohen A (1981) The politics of elit culture: Explorations in the dramaturgy of power in a modern African society. American Political Science Review 75 (4):1070-1071. https://doi.org/10. $2307 / 1962352$.

Creswell JW \& Creswell JD (2017) Research Design: Qualitative, Quantitative, and Mixed Methods Approaches. USA: Sage Publication.

Dahl RA (1989) Democracy and Its Critics. New Haven: Yale University Press.

Dahl RA (2001) Perihal Demokrasi: Menjelajahi Teori dan Praktek Demokrasi Secara Singkat. Jakarta: Obor Indonesia.

Damanik EL (2018a) Pemilihan tanpa kontestasi: Kotak kosong versus kandidat tunggal pada pilkada serentak 2018 di Kabupaten Deli Serdang. In: Setiawan D (ed). Seminar Nasional Tahunan Fakultas Ilmu Sosial Universitas Negeri Medan. Medan: Fakultas Ilmu Sosial Universitas Negeri Medan, 507-511.

Damanik EL (2018b) Politik Lokal: Dinamika Etnisitas pada era Desentralisasi di Sumatra Utara. Medan: Simetri Institute.

Damanik EL (2019a) Ethnic cleavages: The descendant and clan sentiment on the election of regional executives (Pemilukada) in Northern Tapanuli, North Sumatera. Komunitas: International Journal of Indonesian Society and Culture 11 (1):61-76. https://doi.org/10.15294/komunitas. v11i1.17410.

Damanik EL (2019b) Gugung dan Jehe: Pembelahan etnik Karo di Sumatra Utara. Handep: Jurnal Sejarah dan Budaya 3 (1):1-32. https://doi.org/10.33652/handep.v3i1.46.

Derrida J (1978) Writing and Difference.Chicago: University of Chicago Press.

Diamond L \& Gunther R (2001) Types and Function of Parties. In: Diamond L \& Gunther R (eds). Political Parties and Democracy. Baltimore: The John Hopkins University Press.

Freeman S (2007) Justice and the Social Contract: Essays on Rawlsian Political Philosophy. New York: Oxford University Press.

Gill GSG (1995) Pemilu Jurdil: Pengalaman dan Standar Internasional. Jakarta: PIRAC \& The Asia Foundation. 
Goffman E (1959) The Presentation of Self in Everyday Life. USA: Anchor Books.

Huntington SP (1984) Partisipasi Politik di Negara Berkembang. Jakarta: Sangkala Pulsar.

Komisi Pemilihan Umum (2018) Laporan pasangan calon tahap penetapan. [Accessed 28 September 28 2018]. http://infopemilu.kpu.go.id/pilkada2018.

Maisel LS \& Brewer MD (2016) Parties and Election in America: The Electoral Process. Lanham: Rowman \& Littlefield Publisher inc.

Manan F (2015) Pemilihan kepala daerah dengan pasangan calon tunggal dalam pilkada serentak tahun 2015. In: Menyongsong Pilkada Serentak Tahun 2015. Makassar: Universitas Hasanuddin.

Marijan K (2011) Sistem Politik Indonesia: Konsolidasi Demokrasi Pasca-Orde Baru. Jakarta: Kencana.

Norris P (2006) Political Recruitment. In: Schatz WCR (ed). Handbook of Party Politic. London: Sage Publication.

Nurtjahjo H (2006) Filsafat Demokrasi. Jakarta: Bumi Aksara.

Rahat G \& Hazan RY (2001) Candidate selection methods: An analytical framework. Party Politics 7 (3):297-322.

Rawls J (2008) Lectures on the History of Political Philosophy. Harvard: Harvard University Press.

Razaqtiar AZ (2016) Peran partai politik dalam pemilihan kepala daerah: Studi upaya partai Golkar dalam memenangkan pasangan calon Juliyatmono-Rohadi di pemilihan kepala daerah Kabupaten Karanganyar Tahun 2013. Thesis, Universitas Airlangga, Surabaya.

Reynold LT \& Herman-Kinney NJ (2003) Handbooks of Symbolic Interactionism. Lanham: Altamira Press.

Rhodes RAW, Binder SA, \& Rockman BA (2008) The Oxford Handbook of Political Institutions. Oxford: Oxford University Press.

Sari WI (2017) Kontestasi politik: Strategi pemenangan paslon Faida-Muqit dalam Pilkada Jember 2015. Jurnal Politik Muda 6 (3):229-235.

Sarman M (2015) Pilkada Serentak: Quo Vadis Kedaulatan Rakyat. Banjarmasin: Program Magister Sains Administrasi Pembangunan Universitas Lambung Mangkurat.

Schroder P (2008) Strategi Politik. Jakarta: Friedrich-Naumann-Stiftung fur die Freiheit.

Schumpeter JA (2008) Capitalism, Socialism, and Democracy. New York: Harper Perennial Modern Thought.

Situmorang T (2016) Dinamika politik internal partai kebangkitan bangsa dalam proses penentuan kandidat calon Wakil Bupati Sidoarjo 2015. Jurnal Politik Muda 5 (3):342-352.

Surbakti R (2010) Memahami Ilmu Politik. Jakarta: Gramedia Widiasarana Indonesia.

Surbakti R (2011) Merancang Sistem Politik Demokratis: Menuju Pemerintahan Presidensial yang Efektif, Buku I. Jakarta: Kemitraan bagi Pembaruan Tata Pemerintahan.

Triono T (2017) Menakar efektivitas Pemilu serentak 2019. Jurnal Wacana Politik 2 (2):156-164. https://doi.org/10.24198/jwp.v2i2.14205.

Yunus NR (2018) Saat kotak kosong memenangkan pilkada. ADALAH: Buletin Hukum dan Keadilan $2(7): 69-70$. 